\title{
International Short Course in Pictures: Utilizing Photovoice to Promote an Indonesian Student's Intercultural Awareness
}

\author{
Arini Nurul Hidayati' ${ }^{1]}$, Widia Yunita ${ }^{2]}$, Fuad Abdullah $^{3]}$ \\ ${ }_{1,3}^{1,}$ Universitas Siliwangi \\ ${ }^{2}$ Sekolah Tinggi Agama Islam Hubbulwathan \\ E-mail: ${ }^{1]}$ arininurul@unsil.ac.id \\ ${ }^{2]}$ widiayunita@gmail.com \\ ${ }^{2]}$ fuad.abdullah182@gmail.com
}

\begin{abstract}
Capturing moments through photos has now become a common phenomenon in various circles, including academics. It aims to perpetuate every historical value in the life of an individual. In this article, the authors attempt to explore how an Indonesian student experienced her inaugural intercultural journey during a two-month short course program in Ireland, a pathway program to prepare prospective Ph.D students with academic and social skills, through photographs that she took amid the program. This perspective of intercultural travel is embedded in the personal and cultural identities of the participant. This article uses photovoice analysis to exemplify how the participant negotiated her natural identities, institutions, discourses, and affinities during intercultural interaction. The data used in this study are photographs taken by the participant and her voices on those photos guided by the SHOWeD model. The authors employed Pierce's semiotic approach to scrutinize the symbols, icons, and indexes contained in the Photovoice. The results of the analysis indicate that the participant experienced a plethora of moments that aroused her intercultural awareness, starting from managing the initial self-conflicts, adjusting in the fast-paced academic culture by interacting with cultural actors, and responding positively to all stimuli that came during intercultural interactions. Needless to say, challenges are also present as self-development reinforcement. However, this constraint was considered as a self-defense mechanism and an attempt to respect the self, not as a failure of intercultural interaction. In conclusion, the student is currently no longer a cultural observer and imitator, but rather a cultural actor.
\end{abstract}

Keywords: Intercultural awareness, international communication, international short course, photovoice.

\section{Kursus Singkat Internasional dalam Gambar: Memanfaatkan Photovoice untuk Mempromosikan Kesadaran Antar Budaya Seorang Mahasiswa Indonesia}

\begin{abstract}
Abstrak
Mendokumentasikan momen melalui foto kini menjadi fenomena umum di berbagai kalangan, tidak terkecuali para akademisi. Hal tersebut bertujuan untuk mengabadikan setiap nilai yang bersejarah dalam kehidupan seorang individu. Dalam artikel ini, penulis mencoba untuk mengeksplorasi bagaimana seorang mahasiswa Indonesia mengalami perjalanan antar budaya ketika mengikuti program kursus singkat di Irlandia
\end{abstract}


selama dua bulan, sebuah program untuk mempersiapkan calon mahasiswa Ph.D dengan berbagai keterampilan akademik dan sosial, melalui foto yang diambil olehnya selama program berlangsung. Perspektif perjalanan antarbudaya ini tertanam dengan identitas pribadi dan budaya peserta. Artikel ini menggunakan analisis Photovoice untuk menggambarkan bagaimana partisipan menegosiasikan identitas alami, institusional, wacana, dan afinitasnya selama melakukan interaksi antarbudaya. Data yang digunakan dalam penelitian ini adalah berupa foto-foto yang diambil oleh partisipan penelitian dan disuarakan olehnya menggunakan model SHOWeD. Peneliti menggunakan pendekatan semiotika Pierce untuk mengidentifikasi simbol, ikon, dan indeks yang terdapat dalam Photovoice tersebut. Hasil analisis menunjukkan bahwa partisipan mengalami banyak momen yang membangkitkan kesadaran antarbudayanya, mulai dari mengelola konflik dalam dirinya, menyesuaikan diri dalam budaya akademik yang serba cepat melalui interaksi dengan aktor budaya, dan merespon positif semua rangsangan yang datang selama interaksi antar budaya. Tak perlu dikatakan, tantangan juga hadir sebagai penguatan pengembangan diri. Namun, kendala ini dianggap sebagai mekanisme pertahanan diri dan upaya untuk menghormati diri sendiri, bukan sebagai sebuah kegagalan dalam interaksi antarbudaya. Kesimpulannya, seorang mahasiswa Indonesia tersebut saat ini bukan lagi sebagai pemerhati dan peniru budaya, melainkan sebagai pelaku budaya.

Kata kunci: Kesadaran antar budaya, komunikasi antar budaya, kursus singkat internasional, Photovoice.

\section{INTRODUCTION}

When communicating with certain cultural communities, a person would never be able to neglect their personal identity they have earned and built in their own environment. Given this fact, many of the intercultural speakers failed to adapt to a new cultural community. The community is now in the midst of a continuous process of constructing a multiethnic society, which opens up a wide potential for intensive intercultural communication as the recent global migratory trend continues to grow. (Ayber \& Hojeij, 2021). With this in mind, Cuccurullo (2019) contends that intercultural communication is now a model that allows all children and young people to recognize and be aware of each other's identity, as it is oriented toward fostering interaction, dialogue, mutual recognition, and enrichment of any individual, in respect of the different identities of the other; it is an approach that provides a forward-thinking model for managing cultural and linguistic diversity. Thus, as an attempt to realize sustainable intercultural communication, people involved in this interaction should be able to advance the sense of intercultural awareness.

Intercultural awareness is described as non-essentialist views of culture and language that better accounts for their fluid and dynamic relationship (Baker, 2012). This view tries to value people as who they really are, not as the ones with any cultural attributes embedded in them (Hidayati, 2018). Council of Europe (2009) suggests several competencies that are necessary in the interculturality to achieve this awareness, such as respect for otherness, acknowledgement of identities, empathy, tolerance of ambiguity, communicative awareness, critical cultural awareness, knowledge of social 
processes and illustrations of those processes, skills of interpreting and relating, skills of discovery and interaction, and action orientation. These competencies are applied through action, allowing one to understand and respect people who are perceived to have different cultural affiliations than oneself; respond appropriately, effectively, and respectfully when interacting and communicating with such people; establish positive and constructive relationships with them; and understand oneself and one's own multiple cultural affiliations through encounters with cultural dissenters (Barret et al., 2014). The competencies can only be gained through intercultural interactions.

Among the ways to immerse students in intercultural interaction, sending them in a short-course program abroad always becomes an effective alternative. This program provides many benefits for expanding students' horizons. It is believed as one of the best ways for them to achieve personal growth and develop the global mindset (Kamdar \& Lewis, 2015). They continue that short-term study abroad has drawn increased scrutiny for the effectiveness in meeting academic learning objectives. Thus, more and more countries are currently exploring programs for students of diverse levels of education.

Contextually, there was an Indonesian academic who took a shortterm study abroad in Ireland and captured the moments she spent during that two-month program. As an attempt to adjust herself in a new cultural circumstance, she made efforts by documenting her moments and sharing them with families and friends in Indonesia. Sometimes, photos speak louder than words (Lee, et al., 2015). They provide factual information that is able to depict the situation even deeper.
The participant mentioned that reviewing her photographs always intrigues her to arouse intercultural competence as those experiences were among the bridges to build her openmindedness. Furthermore, these experiences also bring an awareness that builds her understanding and acceptance towards people with diverse cultural backgrounds.

There has been ample research in the areas of study abroad and (inter)cultural awareness. For instance, Gutiérrez Almarza et al. (2015) question the relationship between study abroad and the students' cultural awareness which results in a conclusion that there was an enhancement of the students' cultural awareness during the period of their study abroad. Moreover, Koyanagi (2018) contends that short-term study abroad impacts significantly on the students' intercultural communication skills, especially towards adaptability and sensitivity. Furthermore, in a more specific scrutiny, Bandyopadhyay and Bandyopadhyay (2015) highlight the factors contributing to the students' participation in study abroad, one of them was the expectations of having intercultural awareness that would impact on their personal and intellectual growth as well as professional development. Although numbers of studies are growing, the evidence for the development of intercultural awareness, on the other hand, was very limited (Malczewska-Webb, 2014).

Recognizing the dearth of study in the intercultural awareness development, the researchers are interested to conduct this study as an attempt to present factual evidence on how an Indonesian student promotes her intercultural awareness through the photos taken during a two-month shortcourse program in Ireland. Therefore, photovoice analysis is conducted. By 
analyzing the photos taken during the short course program, this study tries to inform the readers about the authentic intercultural experiences of an Indonesian academic who took a shortterm study abroad in the Republic of Ireland. It is also expected that this study can provide new insights to the ones who are willing to study abroad as well as contribute to the expansion of literature in the area of intercultural communication.

\section{METHOD}

The present study employs photovoice as one of the research techniques. Photovoice, defined as a "qualitative research technique in which participants record and reflect on their community through photography" (Novek et al., 2014, p. 451), (1) enables people to record aspects of their daily lives from their own perspectives, (2) provides opportunities for people to attend to aspects of their lives and communities in which they take great pride or have the greatest concerns, and (3) uses photography to catalog social issues in the community (see Lykes, 2000; McIntyre, 2000; and Wang et al., 1998). It is expected to gain an understanding of the dynamic intercultural journey that was experienced, as well as the fluctuating process in the participant's identity contestation, by making meaning through the photos taken by the program participant.

Photovoice offers advantages such as being a tool for program evaluation due to its unique advantages for qualitative research. Increasing the credibility, authenticity, transferability, and consistency of the methodology improves its reliability and validity (Fade, 2003 in Langdon et al., 2014). Furthermore, one aspect of the Photovoice is the collection of images through photography in order to critically examine a specific aspect of an individual's life; it also calls for the individual to use the photographs to advocate for change in a community. (Treadwell \& Taylor, 2017).

Four photographs taken by a 33year-old Indonesian female student who joined a short course program in Ireland from October - December 2019 were chosen as the data of this study. These photos were taken in diverse moments; one first shot after arrival, one photo around campus building, one image in the tourist spot, and one food picture. She used her cell phone camera to capture all the shots. There were actually hundreds of photos taken during the events, however, four of them were considered representative to delineate her intercultural moments. After selecting the pictures, the participant conducted a SHOWeD analysis to reveal what she understood about the situation (Wang et al., 1998). SHOWeD is the abbreviation of the following guiding questions to the photo interpretation:

$$
\begin{aligned}
\mathrm{S}= & \text { What do you see here? } \\
\mathrm{H}= & \text { What is really happening here? } \\
\mathrm{O}= & \text { How does this relate to our lives } \\
& \text { (or your life personally)? } \\
\mathrm{W}= & \text { Why does this situation, concern or } \\
& \text { strength exist? } \\
\mathrm{e}= & \text { How could this image educate the } \\
\mathrm{D}= & \text { Community (class) }
\end{aligned}
$$
After collecting the Photovoice as the data, the researchers conducted an analysis on those pictures using a semiotic approach coined by Charles Sanders Pierce in Chandler (2002). His model of semiotic analysis consists of three pivotal elements, namely icon as a mode of the signified-signifier resemblance, index as an observable and inferable link between the signified and signifier, and symbol as a mode of 
conventional and arbitrary construction between the signified and signifier.

\section{FINDINGS AND DISCUSSION}

In this section, the results of the data analysis are displayed and discussed. From hundreds of photos taken by the participant, the researchers involved her to select four of them to represent her intercultural experiences, comprising the initial conflict after the arrival, fast adjustment with the environment, and series of efforts to cultural adaptation. Long story short, in the end, she was able to negotiate her multi affiliation identity to accept the new perspective of cultures.

\section{Managing Self-Conflict to Advance the Tolerance of Ambiguity}

Being in an unfamiliar sphere sometimes leads people to any inconveniences, more specifically for those who begin to travel and study abroad. Generally, people would experience a honeymoon phase as the initial movement after the arrival in the host country (Hammadova, 2017; Jansen, 2015). The feelings of excitement and amazement are among the representations that accompanied the curiosity of the students in a new place. However, there was an extraordinary situation depicted by the participant in her Photovoice. Instead of focusing on enjoying the sightseeing as other companions did, she tended to be worrisome and anxious. This anxiety refers to not only academic matters but also sociocultural affairs (Dewey et al., 2018; Lee, 2018). To see the clearer condition, the following photo and voices will delineate the participant's initial conflicts in her mind.

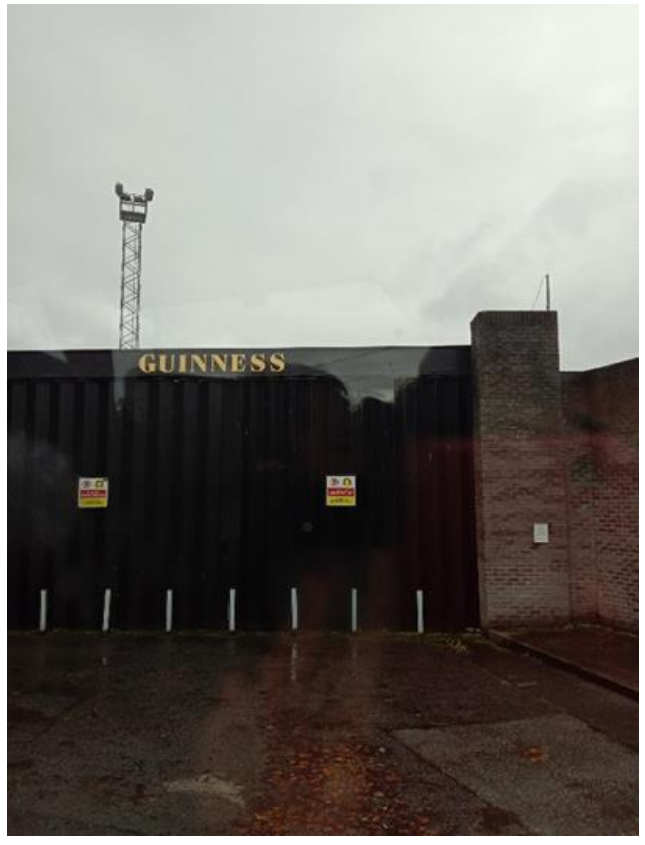

Picture 1. Guinness factory

$\mathrm{S}=$ What is seen in this photo is the gate of the Guinness factory, one of the most successful alcohol companies worldwide. This photo was taken on my way to the Apartment from the Airport as my first footstep in Ireland.

$\mathrm{H}=$ What can't be seen here is the complex feeling wondering what life I would experience in the following two months, what people I would linger with during those periods, and what situations I need to tackle when mingling with the native people.

$\mathrm{O}=$ This relates to other people's life since there are many foreign students taking a short-course abroad and would express different feelings once they arrive in the host country.

$\mathrm{W}=$ The reason $\mathrm{I}$ took this program was because I intended to embark on my $\mathrm{PhD}$ abroad and this journey would give me a glimpse of how the life of an international $\mathrm{PhD}$ student would likely be.

e $=$ This image can educate people by inspiring them to do an intercultural journey to experience new perspectives. By having such experiences, we will grow wiser.

$\mathrm{D}=$ All I need to do is to get up and stop dreaming, but rather go realizing it. 
As long as I have a great intention, effort, and prayer, I believe that the nature will respond to my grants positively.

From Picture 1 and its description, it can be inferred that the participant experienced a turbulence and confusion at the beginning of her arrival. The gray sky represents the feeling of despondency. The more dominant tendency to emerge with this photo representation is anxieties about life that she did not recognize before even she had learned prior to the departure. Her incapability to perceive the unfamiliar environment as desirable delineates the low tolerance of ambiguity (Sharma \& $\mathrm{Su}, 2016)$. Considered as the one with low tolerance of ambiguity, she potentially handles vagueness on an asneeded basis, responding to items as they arise and is overwhelmed by uncertain situations requiring a high level of involvement (Salazar \& Aguiero, 2016). This condition is usually easy to lead people involved in intercultural interaction into depression.

However, in the following statement, she mentioned that this journey was part of her strategic attempts to embark on a PhD. This means that she had already predicted her unreadiness but struggled to cope with that. In her mind, she did a self-talk that she had to begin to develop a repertoire of approaches for dealing with ambiguities in any situations and view them as challenges (Salazar \& Agüero, 2016). The more she kept close to her personal problems, the more difficult she could overcome those obstacles. Therefore, once she realizes her issues, she'd better start to open up, relieve, and move on. At the end, she was aware that selfnegotiation is the only way to bridge her into readiness of acceptance (Gunia et al., 2016). By having such belief, international students are equipped with the advanced tolerance of ambiguity when entering into novel environments.

\section{Expanding Skills of Discovery and Interaction}

International students will normally experience the adjustment's phase such as readiness to leave, having first impression, increasing interaction, experiencing culture shock, and full adaptation (Gebhard, 2012). As the time went by, the participant engaged more naturally with the cultural actors in the host country; with the classmates, teachers, professors, academic staff, and neighbors (Abdullah \& Lulita, 2018). Picture 2 below showcases a brighter view of impression as the intercultural interaction is getting more intense. In detailed explanations, the participant voiced the photo's descriptions.

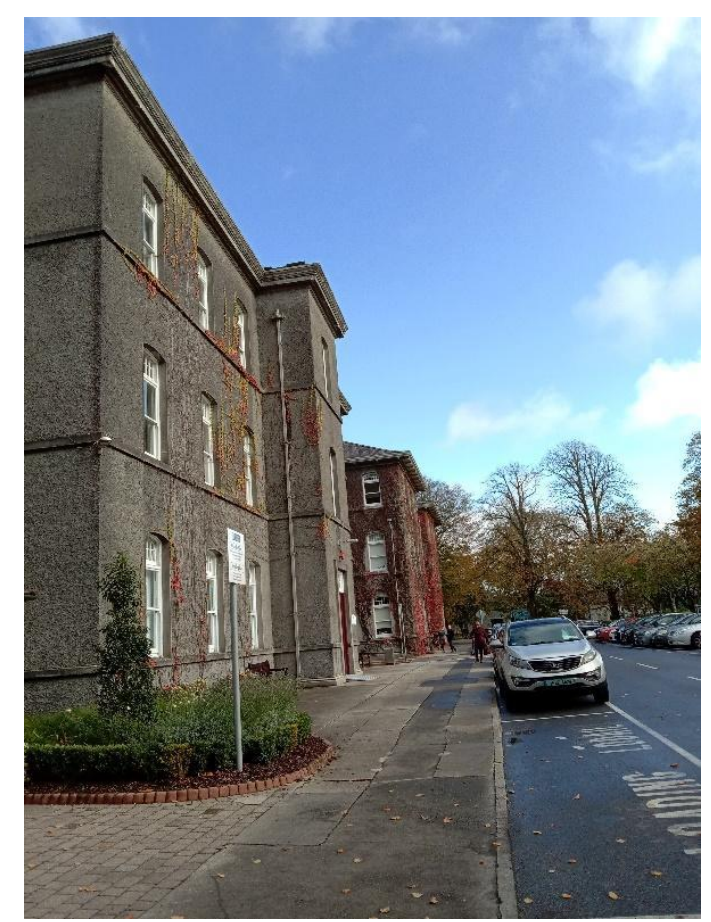

Picture 2. Campus buildings in autumn

$\mathrm{S}=$ What is seen in this photo is the campus buildings and road in the autumn. This photo was taken under a clear sky. Usually, the rain falls down unpredictably. Very luckily, I could take a nice pic on my way to 
the class in the second week of the program.

$\mathrm{H}=$ What is unseen here is my struggle to adapt with different paces of life. I needed to catch the bus every morning, and took a walk in the afternoon to get back. I had classes with many challenging tasks with Irish native instructors and had to travel to six other universities across Ireland to do comparative studies.

$\mathrm{O}=$ This picture relates to other people's life because everyone who attempts to adjust in a novel learning cultural circumstance would experience similar issues in balancing their habits with the target culture.

$\mathrm{W}=$ Another reason why this program was in my wish list is because I believe that one of the ways to develop myself is by being a flexible and curious person; eager to break the common rules and move beyond the limits.

e $=$ This photo gives lessons to the viewers that curiosity and flexibility become two significant factors to social and academic success. By having such traits, people can easily adapt with any circumstances.

$\mathrm{D}=$ What I did to adapt with the faster learning pace was viewing a lot; observing other students and teachers, imitating their positive sides, and blending as often as I can to grasp the way they interact.

From Picture 2, it is seen a representation that depicts joy and enthusiasm. The participant in this phase has gone through the dull impressions she experienced the first time. She is better prepared to encounter any obstacles that may come her way. In fact, she now has more of a desire to develop her abilities using various strategies, such as observing the environment and doing more interactions (Ware, 2013). These strategies enable the individuals to gain new cultural knowledge and cultural practices, as well as the ability to apply existing knowledge, attitudes, and skills in cross-cultural interactions (Byram, 1997). This factor includes a variety of communication modes, such as verbal and nonverbal modes, as well as the development of sociolinguistic, linguistic, and discourse competencies.

The illustration of how the participant had interactions with the new people she met demonstrated that she was actually socially awkward. This awkwardness is a subjective impression caused by a variety of cues, such as a failure to execute motor behaviors, misunderstood intentions, and conflicting personality traits (Kadambi, et al., 2020). The awkwardness is symbolized by a walking person with his back from a distance. This depicts her unwillingness to engage too much with others and tends to choose her own way.

On the contrary, at her voice, it is found that she was trying to be as flexible as possible since this is believed as the way to uplift the adaptation process. Holmes et al. (2015) confirm that the importance of quality and flexibility in developing students' intercultural awareness cannot be overstated. In the intercultural encounters, this can help students recognize variety and complexity in themselves and others. Therefore, the primary needs for practical information should be met first. Moreover, interactive spaces for expressing emotion and feelings are also essential for understanding oneself and others. To assist people in understanding the intercultural concepts, discovery activities may help. For instance, conducting observations on the companions, the academic staff and native teachers' behaviors or questioning everything that triggers the curiosity. This is because intercultural discovery and cultural awareness are manifested not only in personal experience, but also in the collective experience of other cultural actors as a result of social affordances (Chen, 2017). In summary, it can be concluded that the flexibility to 
join a new fellowship could enhance the discovery and interaction skills of international students.

\section{Establishing Positive and Constructive Rapports}

In the following stage, the participant got involved more aggressively in other casual activities, such as traveling with groups of people from different countries. This aimed at expanding her intercultural experiences, thus, she could compare and relate this new experience with the former ones. The skills of comparison, interpreting, and relating are very important in the intercultural interaction since these skills enable people from diverse cultures to put ideas side by side and observe how each may appear from a different perspective, as well as how people misinterpret what is said or written as a result of cultural differences (Byram et al., 2002).

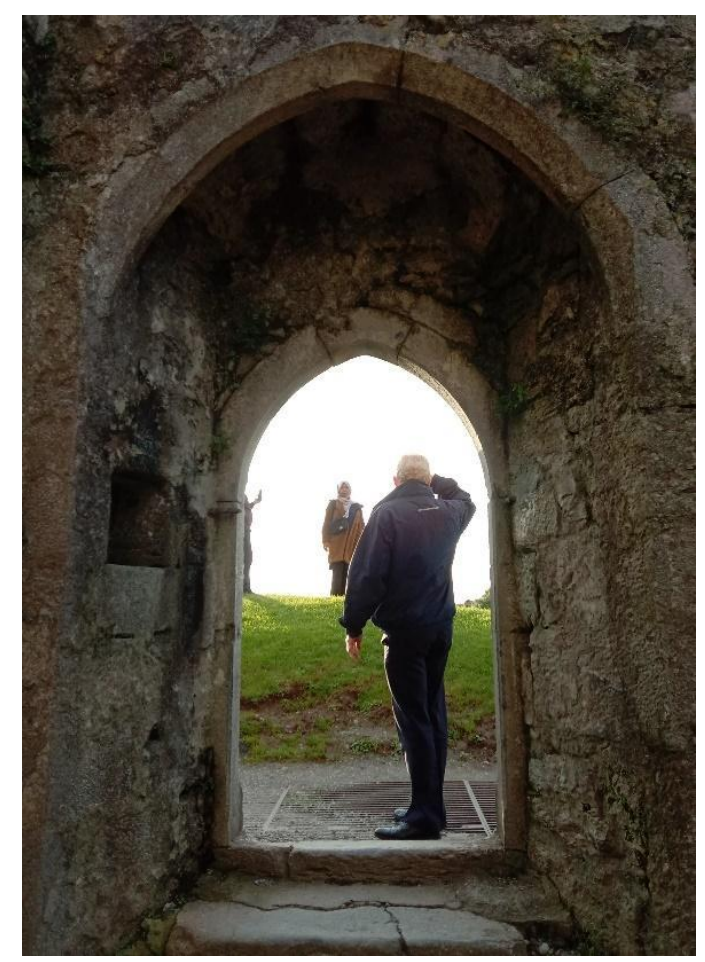

Picture 3. An irish feat an indonesian

$\mathrm{S}=$ What is seen in this photo is an Irish man who was hiding his eyes from the sunshine. He was facing an Indonesian student who was mesmerized with the Ross Erily Friary.

$\mathrm{H}=$ What can't be seen here is my clumsiness when I went on a group tour with people from diverse countries to several tourist spots, such as Aran Islands, Cliffs of Moher, and the Quiet Man city. The tour guide and the driver were native Irish, while the tour mates came from India, Germany, France, England, Switzerland, and Netherlands.

$\mathrm{O}=$ This relates to other people's life because the situation requiring open-mindedness in intercultural communication is not an option, yet it is a must-happen condition. Therefore, when you decide to blend yourself in the intercultural sphere, be open and get ready for the new adventures.

$\mathrm{W}=$ Why I decided to take this trip was because I needed to refresh my brain on weekends after tiring tasks on weekdays. More importantly, these trips were the only way I can use to maximize potentials to expand my intercultural experiences.

e $=$ This image can educate people by informing them the importance of viewing things from diverse perspectives especially when we are engaging in the intercultural community. Making attempts to position ourselves in the interlocutors' viewpoints might be helpful to sharpen our intuition and grow empathy.

$\mathrm{D}=$ What $\mathrm{I}$ could do about this is listen as much as I can when meeting new people, always responding to them in polite manners, and being resourceful by equipping myself with intercultural knowledge.

Picture 3. provides an illustration of two people from different cultural backgrounds trying to have two-way communication. The man in the picture tries to project what his interlocutor is like by observing from a distance, predicting what speech might be conveyed by learning the responses of his interlocutor. Similarly, the woman 
from a distance also pays attention to him and considers what replies are appropriate to keep the conversation run smoothly. This mutual understanding and cooperation regardless of their different social and cultural backgrounds will eventually help them understand each other and live in peace and harmony (Byram, 2002; Chen, 2013). This concludes that intercultural listening and empathy are ways to build successful intercultural communication (Hidayati \& Santiana, 2020). Therefore, listen more and feel more.

\section{Respecting Others and the Self}

A successful communication across cultures definitely involves twosided parties, the self and the other. In line with this, Lan (2020) maintains that only when there is a reflective contact between the self and the other can one speak of intercultural interaction. This relationship has been established to foster trust and confidence. In Picture 4, the participant delineates the respect for her beliefs and identity through a photo of the selected dish; the representation of particular belief held by the participant since childhood.

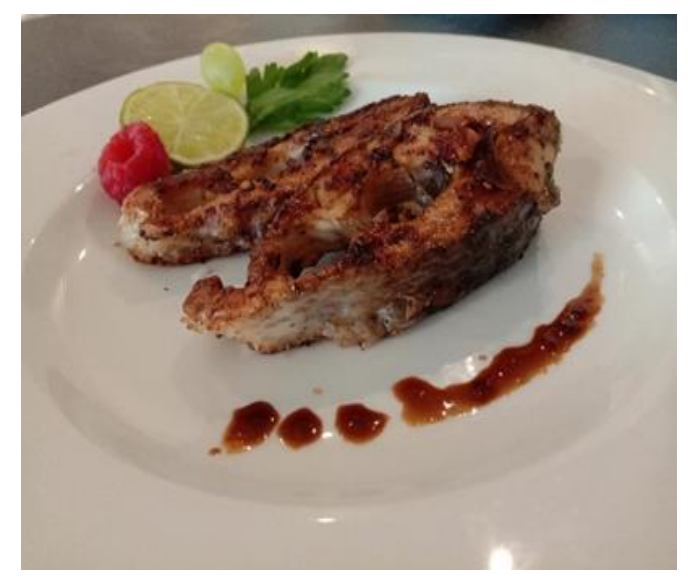

Picture 4. A choice of cuisine

$\mathrm{S}=$ What is seen in this picture is a plate of Tilapia grilled fish with lemongrass sauce garnished by sliced fruits and mint leaves. This is one of the masterpieces of my kitchen experiments.

$\mathrm{H}=$ What was untold behind this image is the high insecurity towards the available foods in town. I was super picky when it came to meals due to my strong belief in the halal and haram label (allowed and not allowed) based on Islamic regulation.

$\mathrm{O}=$ This relates to other people's life since the issue of halal and haram foods has already been discussing worldwide and many Muslim students studying in non-Muslim countries concern a lot on deciding their intakes to protect their beliefs.

$\mathrm{W}=\mathrm{I}$ decided to cook, bringing the meals to wherever I go, every day, every time. Besides, I bought the cooking materials especially meats and chicken from halal food stores, and shopped from supermarkets to buy raw fish and vegetarian menu only.

e $=$ This image can educate people by inspiring them that we might blend with the new community and respect the differences, however, it is also very crucial to preserve our own beliefs in order to prevent us losing identity.

$\mathrm{D}=$ What $\mathrm{I}$ could do about this is always being faithful to what I believe, because to fully respect others begins with respecting the self.

Picture 4. describes that the participant was a quite picky person. In terms of foods, she prefers to choose a 'secure' choice. Food security based on her belief is that which fulfills the provisions of halal and haram. These concepts are actually very broad and debatable. In a nutshell, these provisions are established in the Islamic regulation. Among the consensus, all permissible animals to eat in Islam must be slaughtered according to Islamic rites. Slaughtering ethics must be performed by a mentally capable individual using a sharp cutting tool. Lastly, the halal ingredients must not be combined or come into contact with the haram ones 
such as dog, swine, and alcohol (Samori et al., 2014).

The food symbolizes the effort to protect the participant's belief and identity as a Muslim living in a nonMuslim country (Gardner et al., 2014). In this regard, she tried to develop her competence to critically evaluate perspectives, practices and products of her own and the others. As a result, her role has shifted with the advent of the intercultural communicative approach; she is no longer a passive observer or imitator of target language speakers, but rather an active participant in an exploration of the other and oneself (Byram et al., 2002; Moulin-Doos, 2014). This excerpt indicates the importance of being critical in intercultural interaction as well as a reminder that respecting others does not mean putting aside our own principles in life. Balancing respect for others and oneself is the solution to creating a harmonious relationship in intercultural communication.

\section{CONCLUSION}

Intercultural experiences through international short courses always give a positive impact on increasing students' ability to adapt to new environments, opening new horizons and perspectives, and preparing individuals who are open minded and able to become agents for change. To achieve these goals, intercultural awareness must be disseminated to anyone who intends to conduct intercultural communication. One of them is by distributing it through Photovoice. This study provides illustrations and concrete evidence about the experiences of the participant in overcoming her individual conflicts, dealing with the uncertain situations, trying to accept differences, learning from the environment by observing and imitating, until eventually becoming a cultural actor who is able to sort and choose what to take and not because she appreciates herself and others. This present study has weaknesses, especially in the interpretation process. To get a more comprehensive interpretation, the next researchers could involve the participant by conducting interviews.

\section{REFERENCES}

Abdullah, F. \& Lulita. (2018). Social actors in an Intercultural Communication classroom: A discursive lens of intercultural education. Indonesian JELT, 13(1), 31-51.

Ayber, P. O., \& Hojeij, Z. (2021). Promoting Intercultural Awareness through Stories: A UAE Case. Journal of Teaching and Teacher Education, 9(02).

Baker, W. (2012). From cultural awareness to intercultural awareness: Culture in ELT. ELT Journal, 66(1), 62-70.

Bandyopadhyay, S., \& Bandyopadhyay, K. (2015). Factors influencing student participation in college study abroad programs. Journal of International Education Research (JIER), 11(2), 87-94.

Barrett, G. A., Hayes, A., \& Hollinshead, J. (2019). Study abroad and developing reflective research practice through blogs: A preliminary study from the United Kingdom. Journal of Criminal Justice Education, 30(3), 463-474.

Byram, M. (1997). 'Cultural awareness' as vocabulary learning. Language Learning Journal, 16(1), 51-57.

Byram, M., Gribkova, B., \& Starkey, H. (2002). Developing the intercultural dimension in language teaching: A practical introduction for teachers. 
Language Policy Division, Directorate of School, Out-ofSchool and Higher Education, Council of Europe.

Chandler, D. (2007). Semiotics: the basics. Routledge. Milton Park, Abingdon, Oxfordshire.

Chen, C. (2013). Empathy in language learning and its inspiration to the development of intercultural communicative competence. Theory \& Practice in Language Studies, 3(12).

Chen, H. I. (2017). Intercultural communication in online social networking discourse. Language and Intercultural Communication, 17(2), 166-189.

Council of Europe. (2009). Autobiography of intercultural encounters: Context, concepts and theories. Strasbourg: Author.

Cuccurullo, D. (2019). Autobiographical narrative and intercultural awareness. Journal of e-Learning and Knowledge Society, 15(1).

Dewey, D. P., Belnap, R. K., \& Steffen, P. (2018). Anxiety: stress, foreign language classroom anxiety, and enjoyment during study abroad in Amman, Jordan. Annual Review of Applied Linguistics, 38, 140-161.

Gardner, T. M., Krägeloh, C. U., \& Henning, M. A. (2014). Religious coping, stress, and quality of life of Muslim university students in New Zealand. Mental Health, Religion \& Culture, 17(4), 327-338.

Gebhard, J. G. (2012). International students' adjustment problems and behaviors. Journal of International Students, 2(2), 158164.

Gunia, B. C., Brett, J. M., \& Gelfand, M. J. (2016). The science of culture and negotiation. Current Opinion in Psychology, 8, 78-83.

Gutiérrez Almarza, G., Durán Martínez, R., \& Beltrán Llavador, F. (2015). Identifying students' intercultural communicative competence at the beginning of their placement: towards the enhancement of study abroad programmes. Intercultural Education, 26(1), 73-85.

Hidayati, A. N. (2018). Falling into Culturist Trap: Practice of Othering in an Indonesian English Language Classroom. Jurnal Penelitian Humaniora, 19(1), 1-9.

Hidayati, A. N., \& Santiana, S. (2020). Promoting cultural awareness through intercultural listening activities. Jurnal Tahuri, 17(2), 53-62.

Holmes, P., Bavieri, L., \& Ganassin, S. (2015). Developing intercultural understanding for study abroad: Students' and teachers' perspectives on pre-departure intercultural

learning. Intercultural Education, 26(1), 16-30.

Hommadova, A. (2017). Phases of cultural adjustment of East Asian students. Journal of International and Advanced Japanese Studies, 9, 171-192.

Jansen, E. (2015). Beyond The Honeymoon Phase: A Comparative Analysis of Culture Shock Experienced by Dutch and American Students Abroad (Master's thesis).

Kamdar, N., \& Lewis, T. (2015). Deriving long-term benefits from short-term study-abroad programs. Journal of Management \& Engineering Integration, 7(2), 1. 
Kadambi, A., Ichien, N., Qiu, S., \& Lu, H. (2020). Understanding the visual perception of awkward body movements: How interactions go awry. Attention, Perception \& Psychophysics, 82(5), 25442557.

Koyanagi, S. (2018). Impact of intercultural communication during short-term study-abroad of Japanese students: Analysis from a perspective of cognitive modification. Journal of Intercultural Communication Research, 47(2), 105-120.

Lan, S. W. (2020). Intercultural Interaction in English: Taiwanese University Students' Investment and Resistance in Culturally Mixed Groups. SAGE Open, 10(3), 2158244020941863.

Langdon, J. L., Walker, A., Colquitt, G., \& Pritchard, T. (2014). Using Photovoice to determine preservice Teachers' preparedness to teach. Journal of Physical Education, Recreation \& Dance, 85(1), 22-27.

Lee, E., Lee, J. A., Moon, J. H., \& Sung, Y. (2015). Pictures speak louder than words: Motivations for using Instagram. Cyberpsychology, behavior, and social networking, 18(9), 552556.

Lee, J. H. (2018). The effects of shortterm study abroad on L2 anxiety, international posture, and L2 willingness to communicate. Journal of Multilingual and Multicultural Development, 39(8), 703-714.

Lykes, M. B., \& Scheib, H. (2015). The artistry of emancipatory practice: Photovoice, creative techniques, and feminist anti-racist participatory action research. The SAGE handbook of action research, 131-142.

Malczewska-Webb, B. (2014). Cultural and intercultural awareness of international students at an Australian university. In Awareness in action (pp. 225239). Springer, Cham.

McIntyre, A. (2003). Through the eyes of women: Photovoice and participatory research as tools for reimagining a place. Gender, Place and Culture: A Journal of Feminist Geography, 10(1), 4766.

Moulin-Doos, C. (2014). Intercultural gardens: the use of space by migrants and the practice of respect. Journal of Urban Affairs, 36(2), 197-206.

Novek, S., \& Menec, V. H. (2014). Older adults' perceptions of agefriendly communities in Canada: A photovoice study. Ageing \& Society, 34(6), 1052-1072.

Ruth, A., Brewis, A., Blasco, D., \& Wutich, A. (2019). Long-term benefits of short-term researchintegrated study abroad. Journal of Studies in International Education, 23(2), 265-280.

Salazar, M. G., \& Agüero, M. F. (2016). Intercultural competence in teaching: Defining the intercultural profile of student teachers. Bellaterra Journal of Teaching \& Learning Language \& Literature, 9(4), 41-58.

Samori, Z., Ishak, A. H., \& Kassan, N. H. (2014). Understanding the development of halal food standards: Suggestions for future research. International Journal of Social Science and Humanity, 4(6), 482.

Sharma, P., Wu, Z., \& Su, Y. (2016). Role of personal cultural 
orientations in intercultural service encounters. Journal of Services Marketing, 30 (2), 223227.

Treadwell, S. M., \& Taylor, N. (2017). PE in pictures: using photovoice to promote middle school students' reflections on physical activity during free time. Journal of Physical Education, Recreation \& Dance, 88(4), 2633.

Wang, C. C., Yi, W. K., Tao, Z. W., \& Carovano, K. (1998). Photovoice as a participatory health promotion strategy. Health promotion international, 13(1), 75-86.

Ware, P. (2013). Teaching comments: Intercultural communication skills in the digital age. Intercultural Education, 24(4), 315-326. 